\title{
Formation of Aromatic Compounds from Carbohydrates. VII.* Reaction of D-Glucose and Glycine in Slightly Acidic,
}

\section{Aqueous Solution}

\author{
KJELL OLSSON, PER-AKE PERNEMALM and OLOF THEANDER
}

Department of Chemistry, College of Agriculture, Swedish University of Agricultural Sciences, S-750 07 Uppsala, Sweden

\begin{abstract}
The title reaction produced a humin-like precipitate. In the supernatant, D-fructose and compounds 1-27, comprising furans, pyrroles, pyridines, phenols, carboxylic acids and lactones were identified. 5-(Hydroxymethyl)pyrrole-2-carboxaldehyde (12), 2-formyl-5methylpyrrole-1-acetic acid (14), 6-formyl3,4-dihydro-3-oxopyrrolo[1,2-a]pyrazine-2(1H)acetic acid (16), 5-hydroxy-2-pyridyl methyl ketone (22) and 2-formyl-5-(5-formyl-2-furfuryloxymethyl)pyrrole-1-acetic acid $(27)$ seem to be new compounds. 2-Methyl-3-pyridinol (17) and trans-5-(hydroxymethyl)-2-furanacrylic acid (25) have apparently not been identified previously as degradation products of carbohydrates. The formation of all 12 nitrogen compounds except 22 is rationalized by a reac. tion scheme, based on dehydration of the glucose, with or without Strecker degradation of the glycine.
\end{abstract}

The so-called Maillard reaction between carbohydrates and amino compounds ${ }^{2,3}$ is important in food chemistry and may contribute to the yellowing of cellulosic products. Proteins react mainly through their basic amino acid residues, notably through lysine $\varepsilon$-amino groups. In a recent reinvestigation of the reaction in a simple model system, viz., D-glucose and methylamine in dilute acetic acid," several new products were isolated by means of liquid chromatography. However, both food and wood may contain free amino acids and sugars, and are often processed under conditions, leading to extensive carbohydrate and protein hydrolysis. The Maillard reaction of the amino

\footnotetext{
* Part VI. See Ref. 1.
}

acids (and oligopeptides) differs from that of common primary amines by the occurrence of the Strecker degradation., ${ }^{2,5}$ This paper deals with the reaction between glucose and glycine. The results were reported briefly at a recent meeting. ${ }^{6}$ The same reaction has been studied previously, as discussed below, but few products have been identified.

\section{RESULTS}

The title reaction was performed and the reaction mixture processed essentially as described for the reaction of glucose and methylamine.4 Thus, an aqueous solution of glucose and glycine in the molar ratio 3:2 was refluxed for $120 \mathrm{~h}$. During that time, which was required to approach the maximum yield of extracted material, the $\mathrm{pH}$ dropped from 5.0 to 3.7 , and a dark-brown powder precipitated. The elemental composition of the dry material approximated to $\mathrm{C}_{11.6} \mathrm{H}_{11.4} \mathrm{NO}_{4.0}$. On the basis of eqn. 1 in the discussion, the precipitate accounted for $49 \%$ of the glucose and $43 \%$ of the glycine. Sugar analysis ${ }^{7}$ of the supernatant showed glucose in $26 \%$ of the original amount and a $2.3 \%$ yield of $D$-fructose. The solution was extracted with ethyl acetate, followed by 2-butanone. In view of the fact that 5-(hydroxymethyl)-2-furaldehyde (8) constituted at least half of the extracted material, the latter probably accounted for 5-6\% of the glucose and less than $4 \%$ of the glycine.

CC of the combined extracts on Sephadex LH-20 resulted in eight main fractions $(1-8$, 

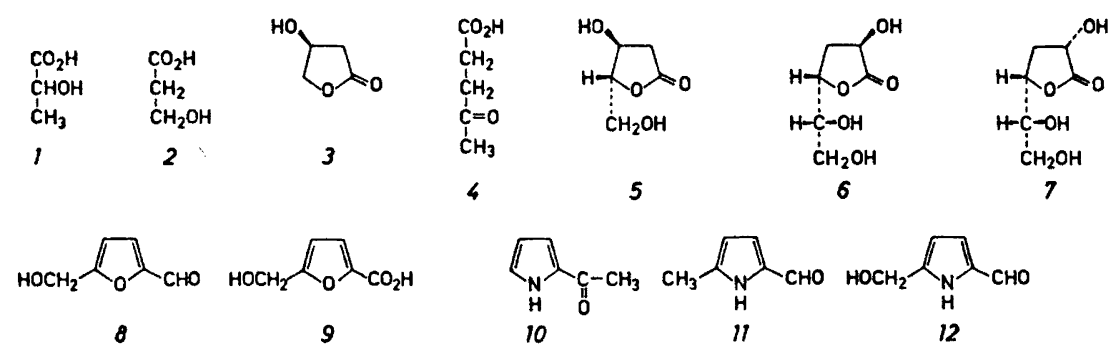<smiles>Cn1c(C=O)ccc1C=O</smiles>

13<smiles>OCc1ccc(O)cn1</smiles>

19<smiles>[X]C(=O)OCc1ccc(C=O)n1CC(=O)O</smiles>

15<smiles>O=Cc1ccc2n1CC(=O)N(CC(=O)O)C2</smiles>

16<smiles>Oc1cccc(O)c1O</smiles>

21<smiles>CC(=O)c1ccc(O)cn1</smiles>

22<smiles>Cc1ccc(O)cn1</smiles><smiles>O=Cc1ccc(O)c(O)c1</smiles>

23

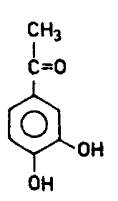

24<smiles>O=CC(C=O)c1ccc(CO)o1</smiles>

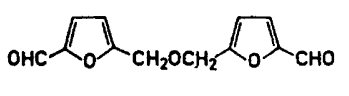

26

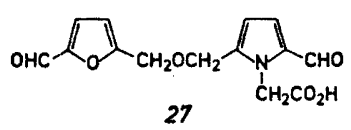

Scheme 1. Identified title reaction products other than D-fructose.

Table 1). Fraction 2 was separated into one more (2H) and one less (2L) hydrophilic subfraction by partial extraction with ethyl acetate, and fraction 3 into one acidic (3A) and one neutral (3N, almost pure 8) subfraction by means of sodium hydrogen carbonate. All fractions except $3 \mathrm{~N}$ were further separated by CC on silica gel, occasionally followed by preparative TLC. In this way, each of the compounds $(1-27)$ in Scheme 1 was isolated in sufficient amount and purity for proper characterization and identification, except for the mutual separation of the minor products 23 and 24. Another three compounds, probably related to 25 , were isolated from fraction 6 but were not identified. The actual yields were estimated from the weights of the evaporated fractions (Table 1) and from the approximate proportions of their components revealed by TLC. Thus, the yield of 8 was ca. $3 \%$; those of 15 and $16 \mathrm{ca} .0 .1 \%$; those of $1-5,9-11$ and $190.01-0.1 \%$; and those of the remaining products $<0.01 \%$. Products 12, 14, 16, 22 and 27 seem to be new compounds, while 17 and 25 have apparently not been identified previously as degradation products of carbohydrates.

Compounds 1-11,13,17-21 and 23-26 were identical (TLC) with authentic samples (using racemic 1 and 3 ). This was confirmed by MS (except for 1-7) and 'H NMR (except for 20,21 and the $23+24$ mixture). The enantiomeric composition of lactic acid (1) was not investigated. Product 3 was laevorotatory and had almost certainly the D-glycero,configuration shown in Scheme 1.8 The molecular formulas of $12,14-16,22$ and 27 were established by high resolution MS and their structures by other spectral data. Allylic couplings $\left(\left.\right|^{4} J \mid 0.6-0.7\right.$ $\mathrm{Hz}$ ) to methyl or methylene protons of 12 and 14-16 permitted complete analysis of their ${ }^{1} \mathrm{H}$ NMR spectra by successive spin decoupling. The formulas were fully confirmed by synthesis, as will be reported in a separate paper.' High resolution MS showed the loss of either substituent from the molecular ion of 16 , supporting the proposed ring system. Remarkable long range coupling $\left(\left.\right|^{5} \mathrm{~J} \mid 1.4 \mathrm{~Hz}\right)$ between its pyrazinone ring protons was observed. The 
${ }^{1} \mathrm{H}$ NMR spectral data for the aromatic protons of 22 established the 2,5-relationship of the substituents. Wolff-Kishner reduction according to the Huang-Minlon procedure ${ }^{10}$ yielded the known 11 6-ethyl-3-pyridinol, identical (TLC, MS and ${ }^{1} \mathrm{H}$ NMR) with a sample prepared from 5-ethyl-2-furaldehyde ${ }^{12}$ and ammonia. The course of the latter reaction is well known.13 The 8 and 15 residues in 27 were revealed by the IR, ${ }^{1} \mathrm{H}$ NMR and high resolution mass spectra as described for closely related anhydrocodimers. The moieties are joined by an ether rather than an ester grouping, since 27 was acid to bromphenol blue and showed a carboxyl proton in its ${ }^{1} \mathrm{H}$ NMR spectrum.

\section{DISCUSSION}

In acidic solution, glucose is largely degraded to 4 and 8 through the enol form of 3-deoxy-Derythro-hexosulose (33, Scheme 2).2,14,15 Further dehydration of 8 may produce $26,4,16$ and in the presence of methylamine some 9 is formed by oxidation or disproportionation of 8.4

In alkaline solution, part of 33 rearranges to the "metasaccharinolactones" 6 and $7^{15,17}$ or is cleaved to $5 .^{18}$ Moreover, part of the initially formed 1,2-enediol tautomerizes further through fructose to the 2,3-enediol. This is dehydrated to the 4- or 1-deoxy-2,3-hexodiulose (30 or 31, respectively)..$^{14,15}$ Retroaldol condensation. of some fructose yields trioses, which are partly degraded to lactic acid (1) through pyruvaldehyde. ${ }^{15}$ Some 30 is cleaved to $3 .^{8}$ More complex fragmentation and recombination reactions yield several phenolic or enolic products containing 6-9 carbon atoms, including 20,23 and 24.10 Traces of such compounds, e.g., 20,21 and 23 , are formed even in slightly acidic solution. ${ }^{16}$ Hydracrylic acid (2) is formed along with several other acids when glucose, ${ }^{20}$ $\mathrm{D}$-xylose or xylan ${ }^{21}$ is oxidized in alkali, probably by a reaction analogous to $30 \rightarrow 3.22$

Hence, all nitrogen-free title reaction products except 25 are known degradation products of glucose, and most of them are formed through a generally accepted reaction route. Several of these compounds are also produced in the presence of methylamine and may obviously appear in food as Maillard reaction products. It is notable that glycine, like alkali, may catalyse tautomerizations, fragmentations and benzilic acid rearrangements, resulting in the formation of $1-3$ and $5-7$. Product 25 may have formed from 8 through initial aldol condensation and dehydration, but the second reactant is unknown. The ethyl acetate used for extraction is not involved, since no 25 was detected after stirring ethyl acetate overnight with an aqueous solution of 8 and glycine.

The origin of 22 is obscure, but all other nitrogenous products from the title reaction are believed to form essentially as shown in Scheme 2. The alternative formation of 10 and 17 through 30 and the 4-deoxy isomers of 35 and 36 seems equally probable but has been excluded from the scheme for clarity. Moreover, amino compounds catalyse carbohydrate degradation through the transient formation of enamines and/or immonium ions (see, for example, the Amadori rearrangement and subsequent reactions ${ }^{2}$ ), and several such species may be formed and hydrolysed before the nitrogen of the final product is introduced. The reactions of these intermediates are faster but otherwise analogous to those of the corresponding enols and (protonated) carbonyl compounds. The reversible incorporation of nitrogen is therefore neglected in Scheme 2. For further simplicity, it is assumed that the nitrogen of products other than 14 is introduced into 30,31 or 33. This choice is arbitrary. Thus, the nitrogen of 18 may enter during the very first reaction step, whereas that of 14 is introduced into 38 or at an even later stage.

Compound 15 was recently identified as a title reaction product, ${ }^{23}$ and its lactone was obtained some years ago by brief heating of the dry reactants at $200^{\circ} \mathrm{C} .{ }^{24}$ In aqueous acetic acid, glucose and methylamine yield the analogous product $13.4^{4,25}$ In that reaction, 13 may be assumed to form through 33 and 40 in analogy to the route $32 \rightarrow 33 \rightarrow 34 \rightarrow 15$ in Scheme 2. The further reaction of 15 with 8 to give 27 is also analogous to that of 13 in the glucose-methylamine reaction, ${ }^{4}$ but the formation of 16 by incorporation of a second glycine molecule into 15 - confirmed in a separate $20 \mathrm{~h}$ experiment at $100^{\circ} \mathrm{C}$ - has apparently no precedent.

The major difference between methylamine and glycine is however the ability of glycine to undergo the Strecker degradation.2,5 In Scheme 2, this has been illustrated in detail for 


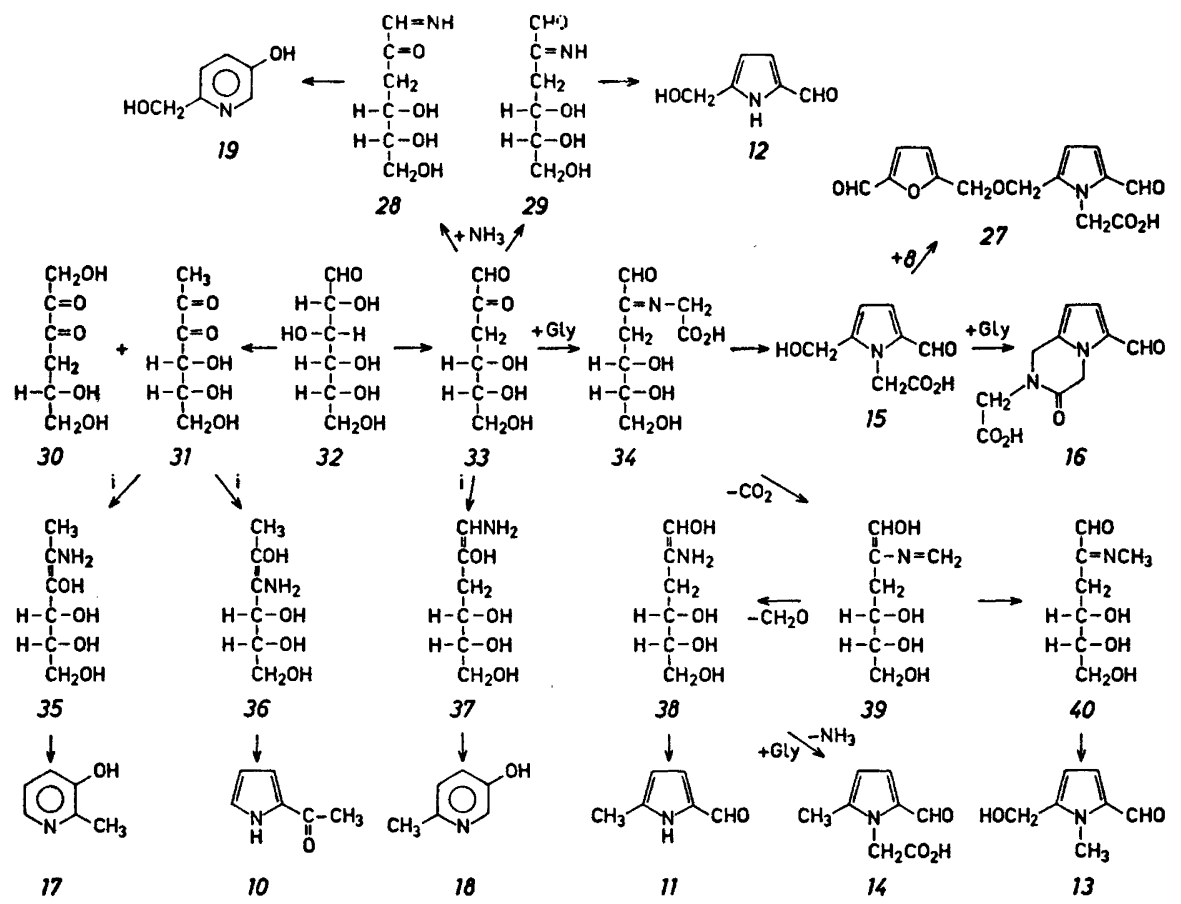

Scheme 2. Main routes to the nitrogenous title reaction products. Gain or loss of $\mathrm{H}_{2} \mathrm{O}$ is not indicated. Gly $=$ glycine and $\mathrm{i}=+\mathrm{Gly}-\mathrm{CO}_{2}-\mathrm{CH}_{2} \mathrm{O}$.

the conversion $33 \rightarrow 38 ; 35$ and 36 are assumed to arise from 31 , and 37 from 33 , in the same way. Further dehydration and cyclization of $35-38$ yield the respective products $17,10,18$ and 11, which are formally derived from ammonia and a reduction product of glucose. Although 18 is also formed along with the expected product 19 when glucose, an ammonium salt and water are kept at $155-165^{\circ} \mathrm{C}$ for $1-3 \mathrm{~h},{ }^{26}$ we detected 12 and 19 but no 18 after performing this reaction at $100^{\circ} \mathrm{C}$ for $20 \mathrm{~h}$. Compounds 10 and 11 have been obtained from D-lactose and $N \alpha$-formyl-L-lysine at $75^{\circ} \mathrm{C}{ }^{27}-$ probably through Strecker degradation of hydrolytically released lysine - and from fructose and ( \pm )-alanine at ca. $100^{\circ} \mathrm{C} .{ }^{28}$ In the latter reaction, 11 was believed to form as outlined in Scheme 2, although the introduction of nitrogen and the Strecker degradation were proposed to occur at a later stage. However, 10 was thought to arise through 33 and (the keto form of) 37. Until this has been confirmed by degradation of an isotopically labelled hexose, we prefer the route in Scheme 2. The proposed intermediacy of 30 or 31 is supported by the isolation of 17 , which could hardly form through 33. Moreover, 30 and 31 are intermediates in the acid-catalysed degradation of fructose. 29 The importance of 30 is indicated by the substantial yield of 2-furyl hydroxymethyl ketone in the fructose-alanine reaction, ${ }^{28}$ and also by the present formation of $3 .^{8}$

In the title reaction, 13 is believed to form via 40 by tautomerization of the Strecker degradation intermediate 39 rather than by decarboxylation of 15 , since no 13 was detected in the experiment $15 \rightarrow 16$ mentioned above. However, higher temperature may favour decarboxylation of 15 , and the l-ethyl homologue of 13 was proposed to form in this way from glucose and alanine at $250^{\circ} \mathrm{C} .{ }^{24}$ Apparently, the same homologue is not formed from fructose and alanine at $100^{\circ} \mathrm{C.} .^{28}$

In the glucose-ammonium salt reaction, 19 was believed to form through $8 .{ }^{26}$ After allowing to reflux overnight, we indeed identified (TLC) 19 in an aqueous solution of 8 and ammonium acetate. The more direct route through an 
intermediate like 28 in Scheme 2 is probably more important, however. Similarly, 12 is assumed to form through 29 or some related species. The ammonia required to convert 33 to 28 and 29 is believed to arise from intermediates like $35-38$ through hydrolysis or exchange with glycine. In the latter case, 38 is converted to 14 .

Because of the Strecker degradation, 10-12 and 17-19 contain only the amino group of glycine. Hence, they are fairly volatile and may form in any reaction between a hexose and an $\alpha$-amino acid. One or several of these products may therefore contribute to the aroma formation in food caused by the Maillard reaction.

The precipitate resembled that obtained from glucose and methylamine but contained slightly more nitrogen. From its elemental composition, the net reaction scheme (eqn. 1) was

$$
\begin{aligned}
& 1.7 \mathrm{C}_{6} \mathrm{H}_{12} \mathrm{O}_{6}+\mathrm{NH}_{2} \mathrm{CH}_{2} \mathrm{CO}_{2} \mathrm{H} \rightarrow \\
& \mathrm{C}_{11.6} \mathrm{H}_{11.4} \mathrm{NO}_{4.0}+7.0 \mathrm{H}_{2} \mathrm{O}+0.6 \mathrm{CO}_{2}
\end{aligned}
$$

derived by disregarding redox processes other than the Strecker degradation and by assuming no net exchange of formaldehyde, ammonia or methylamine between the precipitate and the solution. The latter assumption is, of course, an approximation meaning that all form. aldehyde, ammonia and methylamine liberated during the title reaction are incorporated into the precipitate and the soluble products on a proportional basis. According to eqn. 1, $60 \%$ of the glycine is decarboxylated, the major part probably through Strecker degradation (a minor part may yield products like 13). This suggests that a substantial part of the large precipitate is formed through intermediates like $35-38$, and the same probably applies to the Maillard reaction of other $\alpha$-amino acids. However, the present results permit no safe conclusions about the mechanism of the polymer formation. This accounts for the major discoloration, but the nutritional loss of the amino acid obviously occurs at an earlier stage.

\section{EXPERIMENTAL}

Ge neral

The previous " general procedures were used with the following qualifications. The TLC plates were sprayed with ethanolic $p$-anis- aldehyde-sulfuric acid, aq. iron(III) chloride, phloroglucinol-hydrochloric acid ${ }^{30}$ and aq. sodium hydrogen carbonate-diazotized sulfanilic acid. CC was carried out on Sephadex LH-20 or silica gel (Merck 60, 230-400 mesh). MS data for $M$ and the strongest peaks above $m / e 42$ are listed below. The ${ }^{1} H$ NMR spectra were recorded with methanol- $d_{4}$ as solvent. Data for strongly coupled protons were obtained by $\mathrm{AB}$ or $\mathrm{ABX}$ analysis, ${ }^{31}$ checked by computer simulation and adjusted if necessary. A 620/i computer and a program (assembly No. 995128-00B) from Varian Data Machines were used. In the assignments below, long range couplings to substituents are disregarded, and $2^{\prime}-5^{\prime}$ refer to the lactone protons of 3,6 or 7 behind the plane of Scheme 1 or to the furan ring of $2 \%$.

\section{Materials}

Unless stated otherwise, these were com. mercial samples of good grade. All solvents were freshly distilled before use. The intermediates 5-ethyl-2-furaldehyde, 22,12 2-ethylfuran ${ }^{10,18}$ and 2-methylpyrrole ${ }^{10,23}$ as well as the reference compounds 6-ethyl-3-pyridinol ${ }^{34,11}$ (used to identify 22), ( \pm )-2-deoxytetrono-1,4lactone 13 ; a gift from Professor O. Samuelson, Chalmers Institute of Technology, Gothenburg), 2-deoxy-D-erythro-pentono-1,4-lactone (5), ${ }^{18,36}$ 3-deoxy-D-ribo- (6) and 3-deoxy-Darabino-hexono-1,4-lactone (7), ${ }^{37}$ 5-(hydroxymethyl)-2-furoic acid (9), 5-methylpyrrole-2. carboxaldehyde (11), ${ }^{32,38,38}$ 5-(hydroxymethyl)1-methylpyrrole-2-carboxaldehyde $(13),{ }^{4} 2$. formyl-5-(hydroxymethyl)pyrrole-1-acetic acid (15), 2-methyl-3-pyridinol (17), ${ }^{24,30,40}$ 5-hydroxy-2-pyridinemethanol (19), ${ }^{34,26}$ trans-5-(hydroxymethyl)-2-furanacrylic acid $(25)^{41,42}$ and $5,5^{\prime}$-(oxydimethylene)di-2-furaldehyde $(26)^{16}$ were obtained according to, or in analogy to, the respective references first cited; further references to physical data are given as required. The following spectral data have apparently not been reported.

6-Ethyl-3-pyridinol. MS, m/e (rel. int.): 122 (100), $123(49, M), 95$ (14), 108 (11), 53 (9), 67 (8), 94 (8), 96 (7), 51 (6), 55 (6). ${ }^{1} \mathrm{H}$ NMR: $\delta 1.21\left(\mathrm{CH}_{3}, \mathrm{t}\right), 2.69\left(\mathrm{CH}_{2}, \mathrm{q}\right), 7.13(5-\mathrm{H}, \mathrm{m})$, $7.18 \quad(4-\mathrm{H}, \mathrm{m}), 7.97(2-\mathrm{H}, \mathrm{m}) ;|J| \approx 0.5(2,5)$, $2.7(2,4), 7.5\left(\mathrm{CH}_{3}, \mathrm{CH}_{2}\right), 8.5(4,5) \mathrm{Hz}$.

Compound 3. ${ }^{\mathrm{H}} \mathrm{H} \mathrm{NMR}: \delta 2.36(2-\mathrm{H}, \mathrm{dm})$, $2.79\left(2^{\prime} \cdot \mathrm{H}, \mathrm{dd}\right), 4.20$ (4.H, dm), $4.40\left(4^{\prime} \cdot \mathrm{H}, \mathrm{dd}\right)$, $4.55\left(3^{\prime}-\mathrm{H}, \mathrm{m}\right) ;|J|$ (cf. Ref. 43) $1.1(2,4), 1.4$ $\left(4,3^{\prime}\right), 1.5\left(2,3^{\prime}\right), 4.3\left(3^{\prime}, 4^{\prime}\right), \quad 5.7\left(2^{\prime}, 3^{\prime}\right), 9.5$ $\left(4,4^{\prime}\right)$, $17.7\left(2,2^{\prime}\right) \mathrm{Hz}$.

Compound 6. ${ }^{1 \mathrm{H}} \mathrm{NMR}: \delta 2.11$ (3-H, dt), 2.60 ( $3^{\prime}-\mathrm{H}$, ddd), 3.55 (6- and $\left.6^{\prime}-\mathrm{H}, \mathrm{d}\right), 3.81$ (5-H, m), $4.55\left(2^{\prime} \cdot H, t\right), 4.66(4-H, d t) ;|J| 2.9$ $\left(4,3^{\prime}\right), 3.2(4,5)$, $5.1(5,6), 6.8\left(5,6^{\prime}\right), 8.3\left(3,2^{\prime}\right)$, $8.5\left(2^{\prime}, 3^{\prime}\right), 8.8(3,4), 13.2\left(3,3^{\prime}\right) \mathrm{Hz}$.

Compound 7. ${ }^{1} \mathrm{H}$ NMR: $\delta 2.14\left(3^{\prime} \cdot \mathrm{H}, \mathrm{dt}\right)$, $2.56\left(3-H\right.$, ddd), 3.58 (6- and $\left.6^{\prime}-H, d\right), 3.84$

Acta Chem. Scand. B 32 (1978) No. 4 
(5-H; m), 4.48 (4-H, ddd), 4.54 (2-H, dd); $|J|$ $4.5(4,5), \quad 5.0(5,6), \quad 5.4(3,4), 6.0\left(5,6^{\prime}\right), \quad 8.6$ $(2,3), 10.1\left(4,3^{\prime}\right), 10.9\left(2,3^{\prime}\right), 12.4\left(3,3^{\prime}\right) \mathrm{Hz}$.

Compound 15. MS, m/e (rel. int.): 165 (100), $108(86), 93(65), 44(61), 52(53), 53(52), 80$ (52), 120 (39), 65 (35), 51 (35), 183 (30, M); $\mathrm{M}$, obs. 183.052 , calc. for $\mathrm{C}_{8} \mathrm{H}_{9} \mathrm{NO}_{4} 183.053$. IR $\left(\mathrm{CHCl}_{3}\right), \tilde{\nu}_{\max }: 1660$ (s), 1730 (s), 2300-3600 (m) $\mathrm{cm}^{-1}$. ${ }^{1} \mathrm{H}$ NMR: $\delta 4.57\left(5-\mathrm{CH}_{2}, \mathrm{~s}\right), \quad 5.20$ (1-CH $\mathrm{CH}_{2}$ s), 6.26 (4-H, d), 6.98 (3-H, d), 9.41 (CHO, s); $|J| 4.1 \mathrm{~Hz}$.

Compound 19. MS, m/e (rel. int.): 124 (100), $96(89), 125(60, \mathrm{M}), 94(48), 68(26), 52(25)$, 95 (24), 51 (19), 67 (14), 50 (14). ${ }^{1} \mathrm{H}$ NMR: $\delta 4.59\left(\mathrm{CH}_{2}, \mathrm{~s}\right), 7.24(4-\mathrm{H}, \mathrm{dd}), 7.36(3 . \mathrm{H}$, broad d), $8.02(6-\mathrm{H}, \mathrm{dd}) ; \quad J \mid 0.6(3,6), 2.8(4,6), 8.5$ $(3,4) \mathrm{Hz}$.

Compound 25. MS, m/e (rel. int.): 137 (100), $168(51, M), 65(31), 63(29), 53(24), 81(23), 51$ (23), 55 (22), 109 (22), 121 (22). ${ }^{1} \mathrm{H}$ NMR: $\delta$ $4.55\left(\mathrm{CH}_{2}, \mathrm{~s}\right), 6.24(\alpha-\mathrm{H}, \mathrm{d}), 6.41(4-\mathrm{H}, \mathrm{d}), 6.68$ $(3-H, d), 7.40 \quad(\beta-H, d) ;|J| 3.4(3,4), \quad 15.8$ $(\alpha, \beta) \mathrm{Hz}$.

\section{Title reaction procedure}

A solution of anhydrous D.glucose (1080 g, $6.0 \mathrm{~mol})$ and glycine $(300 \mathrm{~g}, 4.0 \mathrm{~mol})$ in water $(8.0 \mathrm{l})$ was refluxed for $120 \mathrm{~h}$ and then cooled to $20^{\circ} \mathrm{C}$. The dark-brown precipitate was collected, washed with water and dried to constant weight at $60^{\circ} \mathrm{C}$, yielding a hygroscopic amorphous powder $(398 \mathrm{~g})$. For analysis, a portion was further dried at $50^{\circ} \mathrm{C}$ and 0.1 mmHg for $24 \mathrm{~h}$. Found: $\mathrm{C} 60.5 ; \mathrm{H} 4.9 ; \mathrm{N}$ 6.1; O 27.9. Calc. for $\mathrm{C}_{11.6} \mathrm{H}_{11.4} \mathrm{NO}_{4.0} \mathrm{C} 60.0 ; \mathrm{H}$ $5.0 ; \mathrm{N} 6.1 ; \mathrm{O} 28.0$. Apart from a small portion used for sugar analysis," the combined filtrate and washings were extracted with ethyl acetate $(4 \times 1.01)$, followed by 2-butanone $(4 \times 1.01)$. The extracts were combined, dried with sodium sulfate and evaporated.

$\mathrm{CC}$ of the residue $(10.8 \mathrm{~g})$ on an $80 \times 5 \mathrm{~cm}$ Sephadex LH-20 column with water as eluent yielded fractions $1-8$ (Table 1 ). The separation was monitored by TLC with chloroform - glacial acetic acid, 9:1 (v/v), and 2-butanone, saturated with water, as eluents. Fraction 3 was neutralized with sodium hydrogen carbonate. Fractions 1 and 3-8 were extracted with ethyl acetate, followed by 2 -butanone. The extracts from each fraction were combined, dried and evaporated as above. Fraction 2 and the acidified aq. phase from fraction 3 were treated in the same way. The ethyl acetate and 2-butanone extracts from fraction 2 were processed separately, however, yielding fractions $2 \mathrm{~L}$ and $2 \mathrm{H}$, respectively. Fractions $3 \mathrm{~N}$ and $3 \mathrm{~A}$ refer to the extracts from fraction 3 obtained before and after acidification, respectively. Each evapora. tion residue was charged on to a silica gel column. This was eluted with the solvent system listed in Table 1. The separation was monitored by TLC with the same eluent. Evaporation of the purest fractions yielded each of the compounds $1-9,12,14-16,19-22$ and $25-27$ as well as the mixtures $1+17,1+18,8+13$, $10+11$ and $23+24$. Compounds 10, 11, 13, 17 and 18 were isolated by preparative TLC of these mixtures. Compounds 1-22, 25-27 and the $23+24$ mixture were generally obtained as brownish syrups but each in adequate amount and purity. The known products were identical (TLC and spectral data) with the respective reference compounds.

Table 1: CC fractionation of the combined and evaporated extracts from the filtered title reaction mix. ture. Fractions $1-8$ were eluted from Sephadex $L H-20$ with water. $A=$ acidio, $H=$ hydrophilio, $L=l i p o$ philic and $\mathbf{N}=$ neutral indicate aubfractions.

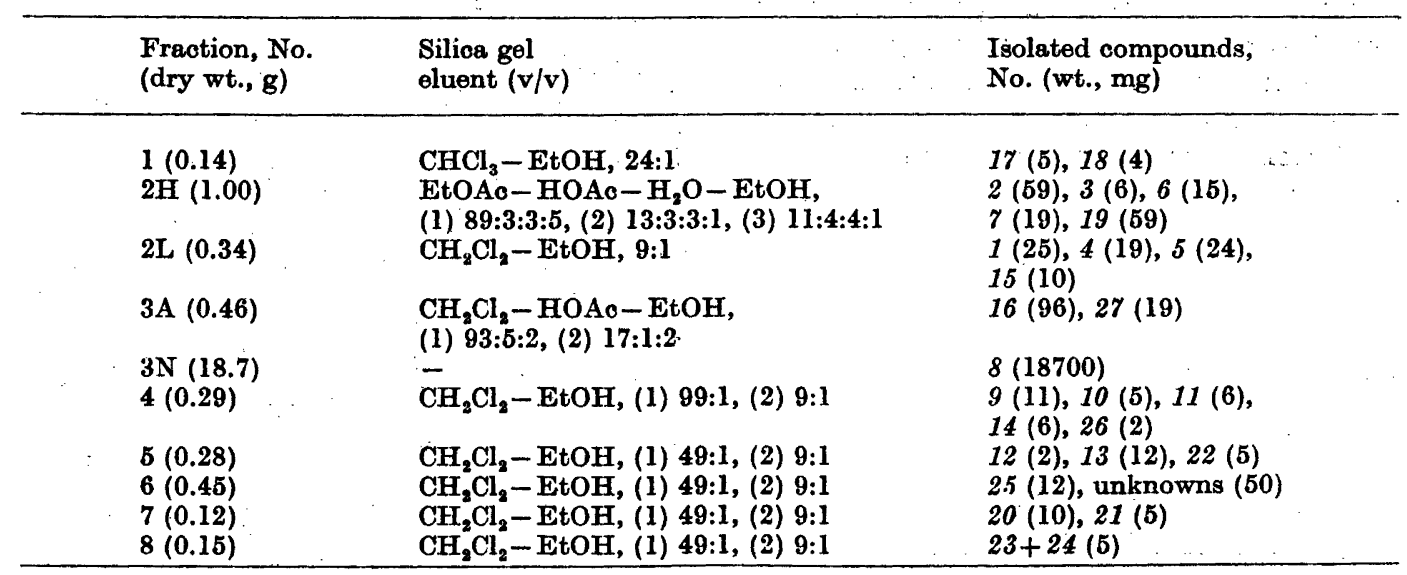


New compounds

Compound 12 was crystallized from benzene and melted at $94-95^{\circ} \mathrm{C}$. MS, $m / e$ (rel. int.): $125(100, M), 68(44), 96(44), 108(37), 52(29)$, 78 (25), 51 (19), 80 (18), 53 (17), 79 (15); M, obs. 125.047, calc. for $\mathrm{C}_{6} \mathrm{H}_{7} \mathrm{NO}_{2}$ 125.048. IR $\left(\mathrm{CHCl}_{3}\right), \tilde{\nu}_{\max }: 1645(\mathrm{~s}), 3440(\mathrm{~m}) \mathrm{cm}^{-1} .{ }^{1} \mathrm{H}$ NMR: $\delta 4.60\left(\mathrm{CH}_{2}, \mathrm{~s}\right), 6.26(4-\mathrm{H}, \mathrm{d}), 6.96(3-\mathrm{H}, \mathrm{d})$, 9.37 (CHO, s); $|J| 3.9 \mathrm{~Hz}$.

Compound 14 was crystallized from benzene and melted at $148-149^{\circ} \mathrm{C}$. MS, $m / e$ (rel. int.): $167(100, \mathrm{M}), 122(68), 94(64), 123(48), 53(40)$, 93 (39), 108 (31), 78 (24), 92 (24), 138 (23); M, obs. 167.060 , calc. for $\mathrm{C}_{8} \mathrm{H}_{8} \mathrm{NO}_{3} 167.058$. IR $\left(\mathrm{CHCl}_{8}\right), \tilde{\vartheta}_{\text {max }}: 1655(\mathrm{~s}), 1740(\mathrm{~m}), 2300-3550(\mathrm{w})$ $\mathrm{cm}^{-1}$. ${ }^{1} \mathrm{H}$ NMR: $\delta 2.24\left(\mathrm{CH}_{3}, \mathrm{~s}\right), 5.12\left(\mathrm{CH}_{2}, \mathrm{~s}\right)$, $6.10(4-\mathrm{H}, \mathrm{d}), 6.96(3-\mathrm{H}, \mathrm{d}), 9.29$ (CHO, s); $|J| 4.1 \mathrm{~Hz}$.

Compound 16 was crystallized from $95 \%$ ethanol and melted at ca. $200^{\circ} \mathrm{C}$ (decomp.). MS, $m / e$ (rel. int.): 163 (100), $222(63, \mathrm{M}), 135$ (63), $108(56), 43(40), 93(33), 52(27), 65(27)$, 51 (21), 92 (21),..., 193 (13); M, obs. 222.064, calc. for $\mathrm{C}_{10} \mathrm{H}_{10} \mathrm{~N}_{2} \mathrm{O}_{4} 222.064 ; \mathrm{M}-\mathrm{CH}_{2} \mathrm{CO}_{2} \mathrm{H}$, obs. 163.051, calc. for $\mathrm{C}_{8} \mathrm{H}_{7} \mathrm{~N}_{2} \mathrm{O}_{2} 163.051 ; \mathrm{M}-$ 'CHO, obs. 193.060 , calc. for $\mathrm{C}_{9} \mathrm{H}_{9} \mathrm{~N}_{2} \mathrm{O}_{3} 193.061$. IR $\left(\mathrm{CHCl}_{3}\right), \tilde{\nu}_{\text {max }}: 1660$ (s), 1730 (m), 2300$3550(w) \mathrm{cm}^{-1} \cdot{ }^{1} \mathrm{H}$ NMR: $\delta 4.28\left(2 \cdot \mathrm{CH}_{2}, \mathrm{~s}\right)$, 4.75 (1- $\mathrm{H}_{2}$, broad s), $5.08\left(4-\mathrm{H}_{2}, \mathrm{t}\right), 6.22(8-\mathrm{H}$, dt), 7.09 (7-H, d), 9.43 (CHO, s); $|J| 0.7(1,8)$, $1.4(1,4), 4.1(7,8) \mathrm{Hz}$.

Compound 22 was obtained as a syrup. MS, $m / e$ (rel. int.): 94 (100), 137 (68, M), 43 (65), 95 (61), 122 (28), 109 (26), 51 (11), 66 (10), 68 (9), 53 (9); M, obs. 137.047 , calc. for $\mathrm{C}_{7} \mathrm{H}_{7} \mathrm{NO}_{2}$ 137.048. IR $\left(\mathrm{CHCl}_{3}\right), \tilde{\nu}_{\max }: 1575$ (s), 1685 (s), $\approx 3200$ (s, broad), $3550(\mathrm{w}) \mathrm{cm}^{-1}$. ${ }^{1} \mathrm{H}$ NMR: $\delta 2.59\left(\mathrm{CH}_{3}, 8\right), 7.23$ (4-H, dd), 7.93 (3-H, d), $8.17(6-\mathrm{H}, \mathrm{d}) ;|J| \approx 0.7(3,6), 3.0(4,6), 8.8$ $(3,4) \mathrm{Hz}$. Wolff-Kishner reduction ${ }^{10}$ of 22 yielded 6-ethyl-3-pyridinol, identical (TLC, MS and ${ }^{1} \mathrm{H}$ NMR) with the reference compound.

Compound 27 was crystallized from chloroform and melted at $127-128^{\circ} \mathrm{C}$. MS, $m / e$ (rel. int.): 108 (100), 110 (98), 109 (94), 138 (76), 166 (54), 53 (53), 167 (51), $136(49), 81$ (34), 80 (34),.., 291 (2, M); M, obs. 291.075, calc. for $\mathrm{C}_{14} \mathrm{H}_{12} \mathrm{NO}_{6} 291.074 ; 8$ residue; obs. 109.031 , calc. for $\mathrm{C}_{6} \mathrm{H}_{6} \mathrm{O}_{2} 109.029 ; 15$ residue, obs. 166.050, calc. for $\mathrm{C}_{8} \mathrm{H}_{8} \mathrm{NO}_{3} 166.050$. IR $\left(\mathrm{CHCl}_{3}\right), \tilde{v}_{\max }: 1660$ (s), 1675 (sh), $1725(\mathrm{~m})$, $2400-3550$ (w), 3640 (w) $\mathrm{cm}^{-1}$. ${ }^{1} \mathrm{H}$ NMR: $\delta 4.51\left(2^{\prime}-\mathrm{CH}_{2}, \mathrm{~s}\right), 4.61\left(5-\mathrm{CH}_{2}, \mathrm{~s}\right), 5.14\left(1-\mathrm{CH}_{2}\right.$, s), 6.34 (4-H, d), 6.61 (3'-H, d), $7.00(3-\mathrm{H}, \mathrm{d})$, $7.34\left(4^{\prime} \cdot \mathrm{H}, \mathrm{d}\right), 9.45$ (2-CHO, s), 9.55 (5'-CHO, s); $|J| 3.6\left(3^{\prime}, 4^{\prime}\right), 4.0(3,4) \mathrm{Hz}$. In $\mathrm{CDCl}_{3}$, an additional signal at $\delta 8.8\left(\mathrm{CO}_{2} \mathrm{H}\right.$, broad s) appeared.

Compounds 12,14 and 16 were identical (TLC, MS and ${ }^{1} \mathrm{H}$ NMR) with the respective synthetic samples. ${ }^{\circ}$

Acknowledgements. We thank Mr. Rolf Andersson and Mr. Suresh Gohil for recording the spectra. Grants from Stiftelsen Bengt Lundqvists minne and the Swedish Board for Technical Development are gratefully acknow. ledged.

\section{REFERENCES}

1. Popoff, T., Theander, O. and Westerlund, E. Acta Chem. Scand. B 32 (1978) 1.

2. Gottschalk, A. In Gottschalk, A., Ed., Glycoproteins, 2nd Ed., Elsevier, Amsterdam 1972, Vol. 5A, p. 141.

3. Feeney, R. E., Blankenhorn, G. and Dixon, H. B. F. Adv. Protein Chem. 29 (1975) 135.

4. Olsson, K., Pernemalm, P.-A., Popoff, T. and Theander, O. Acta Chem. Scand. B 31 (1977) 469 .

5. Baddar, F. G. J. Chem. Soc. (1949) S 163; Schönberg, A. and Moubacher, R. Chem. Rev. 50 (1952) 261 .

6. Pernemalm, P.-A., Popoff, T. and Theander, O. Eighth International Symposium on Carbohydrate Chemistry, $A b$ stracts, Kyoto 1976, p. 22.

7. Sweeley, C. C., Bentley, R., Makita, M. and Wells, W. W. J. Am. Chem. Soc. 85 (1963) 2497.

8. Blears, M. J., Machell, G. and Richards, G. N. Chem. Ind. Iondon (1957) 1150; Machell, G. and Richards, G. N. J. Chem. Soc. (1960) 1924 and 1932.

9. Pernemalm, P.-A. and Olsson, K. To be published.

10. Huang-Minlon, J. Am. Chem. Soc. 68 (1946) 2487.

11. Gruber, W. Can. J. Chem. 31 (1953) 1181.

12. Traynelis, V. J., Miskel, J. J., Jr. and Sowa, J. R. J. Org. Chem. 22 (1957) 1269.

13. Bosshard, $\mathrm{P}$. and Eugster, C. H. Adv. Heterocycl. Chem. 7 (1966) 451.

14. Anet, E. F. L. J. Adv. Carbohydr. Chem. 19 (1964) 181 .

15. Feather, M. S. and Harris, J. F. $A d v$. Carbohydr. Chem. Biochem. 28 (1973) 161.

16. Popoff, T. and Theander, O. Acta Chem. Scand. $B 30$ (1976) 397.

17. Kort, M. J. Adv. Carbohydr. Chem. Biochem. 25 (1970) 311, and references therein.

18. Machell, G. and Richards, G. N. J. Chem. Soc. (1960) 1938.

19. Forsskåhl, I., Popoff, T. and Theander, $O$. Carbohydr. Res. 48 (1976) 13.

20. Samuelson, O. and Stolpe, L. Acta Chem. Scand. 27 (1973) 3061.

21. Malinen, R. and Sjöström, E. Pap. Puu 57 (1975) 101.

22. Kolmodin, H. and Samuelson, O. Sven. Papperstidn. 76 (1973) 71.

23. Kato, H., Sonobe, H. and Fujimaki, M. Agric. Biol. Chem. 41 (1977) 711.

24. Shigematsu, H., Kurata, T., Kato, H. and Fujimaki, M. Agric. Biol. Chem. 35 (1971) 2097. 
25. Jurch, G. R., Jr. and Tatum, J. H. Carbohydr. Res. 15 (1970) 233; Kato, $\mathrm{H}$. and Fujimaki, M. Agric. Biol. Chem. 34 (1970) 1071.

26. Aso, K. Nippon Nogei Kagaku Kaishi 15 (1939) 629; 16 (1940) 249; see Bull. Agric. Chem. Soc. Jpn. 15 (1939) 107; Chem. Abstr. 34 (1940) 431, 6278.

27. Ferretti, A. and Flanagan, V. P. J. Agric. Food Chem. 21 (1973) 35.

28. Shaw, P. E. and Berry, R. E. J. Agric. Food Chem. 25 (1977) 641.

29. Shaw, P. E., Tatum, J. H. and Berry, R. E. Carbohydr. Res. 5 (1967) 266.

30. Clifford, M. N. J. Chromatogr. 94 (1974) 321.

31. Emsley, J. W., Feeney, J. and Sutcliffe, L. H. High Resolution Nuclear Magnetic Resonance Spectroscopy, Pergamon, Oxford 1965 , Vol. 1, pp. 319, 359.

32. Silverstein, R. M., Ryskiewicz, E. E. and Willard, C. In Rabjohn, N., Ed., Org. Synth. Coll. Vol. 4 (1963) 831.

33. Gronowitz, S., Hörnfeldt, A.-B., Gestblom, B. and Hoffman, R. A. Ark. Kemi 18 (1961) 133 .

34. Rapoport, H. and Volcheck, E. J., Jr. J. Am. Chem. Soc. 78 (1956) 2451.

35. Nef, J. U. Justus Liebigs Ann. Chem. 376 (1910) 35 .

36. Nakaminami, G., Shioi, S., Sugiyama, Y., Isemura, S., Shibuya, M. and Nakagawa, M. Bull. Chem. Soc. Jpn. 45 (1972) 2624.

37. Kenner, J. and Richards, G. N. J. Chem. Soc. (1954) 278.

38. Ferretti, A. and Flanagan, V. P. J. Jairy Sci. 54 (1971) 1764.

39. Undheim, K. and Hurum, T. Acta Chem. Scand. 26 (1972) 2075.

40. Brügel, W. Z. Elektrochem. 66 (1962) 159.

41. Rajagopalan, S. and Raman, P. V. A. In Horning, E. C., Ed., Org. Synth. Coll. Vol. 3 (1955) 425, Method A.

42. Karashima, J. Hoppe-Seyler's Z. Physiol. Chem. 180 (1929) 241.

43. Johnson, R. N., Lowry, J. B. and Riggs, N. V. Tetrahedron Lett. (1967) 5113.

Received November 14, 1977. 